\title{
Phase Distribution During Slag Formation in Mn Ferroalloy Production
}

\author{
TICHAONA MUKONO, MARIA WALLIN, and MERETE TANGSTAD
}

\begin{abstract}
Phase development during slag formation and reduction of Comilog and Assmang ores in a setup that simulates the conditions in an industrial SAF process under different coke bed temperatures, $1473 \mathrm{~K}\left(1200{ }^{\circ} \mathrm{C}\right), 1673 \mathrm{~K}\left(1400{ }^{\circ} \mathrm{C}\right)$ and $1773 \mathrm{~K},\left(1500{ }^{\circ} \mathrm{C}\right)$ was investigated. Graphite crucibles were utilized to contain the charge and as a heating element in an induction furnace. A temperature profile was established, cross-sectional excavations were made, and samples were core drilled at selected positions. The resultant phases, i.e., slag and metal, were examined in an electron probe microanalyzer (EPMA) coupled with wavelength-dispersive spectrometry (WDS). The equilibrium phase relations in the $\mathrm{MnO}-\mathrm{SiO}_{2}-\mathrm{CaO}-\mathrm{MgO}-\mathrm{Al}_{2} \mathrm{O}_{3}$ oxide system were calculated using FactSage 7.3 thermochemical software. Differences in ore compositions revealed significant differences in phase development during slag formation and reduction behavior of these manganese sources. The phase development is highly influenced by temperature and position in relation to the coke bed, with a two-phase region, i.e., manganosite + liquid, dominant on top of the coke bed and a dominant liquid slag inside the coke bed. The solid monoxide phase in Comilog has been found to be purely MnO. In contrast to Comilog, the solid monoxide solution phase in Assmang has significantly high $\mathrm{FeO}$ content and forms a $(\mathrm{Mn}, \mathrm{Mg}, \mathrm{Fe}) \mathrm{O}$ solid solution, which becomes more enriched in $\mathrm{MgO}$ with increases in temperature and reduction extent. Due to lower concentration of $\mathrm{CO}$ gas for prereduction in this experimental setup, iron oxides are reduced to $\mathrm{FeO}$ instead of $\mathrm{Fe}$ and subsequently $\mathrm{FeO}$ is stabilized in the monoxide solid solution.
\end{abstract}

https://doi.org/10.1007/s11663-022-02441-5

(C) The Author(s) 2022

\section{INTRODUCTION}

THE primary use of manganese metal is in the steel industry, where it is an alloying constituent mainly added in the form of ferroalloy. ${ }^{[1-4]}$ Industrially, production of ferromanganese alloys is done in submerged arc furnaces (SAF) or blast furnaces. SAF offers a more flexible way of producing manganese ferroalloys compared to the blast furnace in the sense that both manganese ferroalloys with and without silicon can be produced. Production of manganese ferroalloys with silicon requires higher temperatures; hence, blast furnace cannot be used to produce this product, and, as such, the major part of global ferroalloy production is

TICHAONA MUKONO, MARIA WALLIN, and MERETE TANGSTAD are with the Department of Material Science and Engineering, Norwegian University of Science and Technology, Alfred Getz vei 2, 7034 Trondheim, Norway. Contact e-mail: tichaona.mukono@ntnu.no

Manuscript submitted August 8, 2021; accepted January 7, 2022.

Article published online February 6, 2022. through submerged arc furnaces (SAFs). ${ }^{[2,5-8]}$ In this article, the production of $\mathrm{Mn}$ ferroalloys containing $<1$ pet $\mathrm{Si}$ will be discussed.

The feed materials for the high carbon ferromanganese $(\mathrm{HCFeMn})$ submerged arc furnace process contain oxides that undergo reduction as well as non-reduceable oxides. The reduceable oxides are mainly oxides of manganese and iron, which when reduced become part of the alloy phase $(\mathrm{Mn}-\mathrm{Fe}-\mathrm{C})$. The non-reduceable oxides are $\mathrm{CaO}, \mathrm{MgO}, \mathrm{BaO}, \mathrm{Al}_{2} \mathrm{O}_{3}$, and $\mathrm{SiO}_{2}$, to mention but a few, which chiefly become part of the slag phase. In $\mathrm{HCFeMn}$ production, the main oxides of manganese ores include pyrolusite $\left(\mathrm{MnO}_{2}\right)$, bixbyite $\left(\mathrm{Mn}_{2} \mathrm{O}_{3}\right)$ and hausmanite $\left(\mathrm{Mn}_{3} \mathrm{O}_{4}\right)$ as well as other natural minerals that could be present including braunite $\left(3 \mathrm{Mn}_{2} \mathrm{O}_{3} \cdot \mathrm{MnSiO}_{3}\right)$, calcite $\left(\mathrm{CaCO}_{3}\right)$, manganite $(\gamma-\mathrm{MnOOH})$, jacobsite $\left(\mathrm{Fe}_{2} \mathrm{MnO}_{4}\right)$ and other associated minerals. $^{[1,9]}$

Ferromanganese production in a SAF occurs mainly through the carbothermal reduction of manganese oxides. The space between the electrodes and furnace shell in the SAF is filled with burden materials, and electrical energy is converted to heat at the electrode tip to attain smelting temperatures. A temperature gradient develops in the furnace through heat exchange between 
descending burden materials and hot ascending $\mathrm{CO}$ gas generated from the smelting reactions. The furnace is typically divided into two main zones, namely the prereduction zone and coke bed zone. Initially, iron oxides and higher manganese oxides $\left(\mathrm{MnO}_{2}, \mathrm{Mn}_{2} \mathrm{O}_{3}\right.$ and $\mathrm{Mn}_{3} \mathrm{O}_{4}$ ) contained in manganese ores are pre-reduced in the pre-reduction zone by means of $\mathrm{CO}$ gas to metallic $\mathrm{Fe}$ and $\mathrm{MnO}$. Subsequently, the $\mathrm{MnO}$ is reduced in the coke bed zone from liquid slag to $\mathrm{Mn}$ metal by means of solid carbon. ${ }^{[10-15]}$

The coke bed zone is the high-temperature zone of the $\mathrm{SAF}$ where the main $\mathrm{Mn}$ formation takes place. The oxide materials from the prereduction zone are now mainly $\mathrm{MnO}, \mathrm{SiO}_{2}, \mathrm{CaO}, \mathrm{MgO}$ and $\mathrm{Al}_{2} \mathrm{O}_{3}$. The pre-reduced ore contains a variety of different phases given by the original ore minerals. The minerals will sinter, soften and melt down to form a slag as they enter the coke bed zone, where the final reduction with coke or carbon dissolved in the metal takes place according to reaction [1]. The standard reaction enthalpy for reaction [1] is based on thermodynamic calculation using HSC Chemistry ${ }^{\circledR}$ software, version 10.0.4.3, ${ }^{[16]}$

$$
\begin{gathered}
\mathrm{MnO}_{(\mathrm{l})}+\mathrm{C}_{(\mathrm{s})}=\mathrm{Mn}_{(\mathrm{l})}+\mathrm{CO}_{(\mathrm{g})} \\
\Delta H_{298}^{0}=+258.7 \mathrm{~kJ} / \mathrm{mol}
\end{gathered}
$$

The temperature for initial melting has been measured for several $\mathrm{Mn}$ sources using sessile drop and TGA techniques, and investigations show that at the temperature where the Mn sources start to melt, the softening temperature varies between the different $\mathrm{Mn}$ sources from around $1250{ }^{\circ} \mathrm{C}$ to nearly $1600{ }^{\circ} \mathrm{C} \cdot{ }^{[17-20]}$ In general, the initial melting temperature decreases with the increasing amount of acidic oxides in the ore and subsequently increases the reduction rate. In addition, $\mathrm{MnO}$ reduction rates are higher for manganese ores containing higher content of iron minerals. ${ }^{[15,21-23]}$ This is mainly due to a lowering of the $\mathrm{Mn}$ activity in the presence of $\mathrm{Fe}$ and $\mathrm{C}$, as a lower $\mathrm{Mn}$ activity in the $\mathrm{Fe}-\mathrm{Mn}-\mathrm{C}$ alloy phase will drive reaction [1] to the right. Fluxes added influence the smelting process by altering the activities of the oxides in slag, viscosities, melting temperature and electrical conductivity properties of the slag. Slags in FeMn processes are $\mathrm{MnO}-\mathrm{CaO}-\mathrm{MgO}-\mathrm{Al}_{2} \mathrm{O}_{3}-\mathrm{SiO}_{2}$ based and have a quite large composition range depending on manganese ore and its associated gangue minerals. The slag of a typical ferromanganese operation can be referred to as either a 'high $\mathrm{MnO}$ slag' or 'discard slag' depending on the furnace operation. ${ }^{[1,10,24]}$ In the tapped slag the $\mathrm{MnO}$ contents are around 8-15 wt pet in 'discard slag' practice and $>25$ wt pet $\mathrm{MnO}$ in high $\mathrm{MnO}$ slag practice. The high $\mathrm{MnO}$ slag is usually used as a raw material in silicomanganese production, thus increasing the overall $\mathrm{Mn}$ recovery. The reduction of $\mathrm{MnO}$ in slag to the final alloy product is the most important and thermodynamically difficult process step in the production of HCFeMn alloy. Laboratory investigations have been conducted extensively by several researchers to understand the formation of slag and the reduction to metal in the HCFeMn process. ${ }^{[17-20,25-27]}$
The reduction behavior of different ore materials in the FeMn process is different as they possess different variations in ore chemistry, mineralogy and melting properties. Although information can be found in the literature ${ }^{[17-20,25-28]}$ on phase development during slag formation in the FeMn process, some reduction behaviors from specific manganese ores require clarification. As such, the main objective of this study is to investigate the smelting and reduction behavior of Comilog and Assmang ores in a setup that simulates the temperature gradient of industrial SAF processes. The main goal is to compare the phase distributions and reduction behavior of the two compared ores.

\section{EXPERIMENTAL METHODOLOGY}

\section{A. Charge Materials}

The manganese ores used in this study were Comilog and Assmang. Assmang is a Wessels-type ore, which contains both braunite-I and braunite-II minerals $\left(\mathrm{MnO} \cdot 3 \mathrm{Mn}_{2} \mathrm{O}_{3} \cdot \mathrm{SiO}_{2}\right)$, bixbyite $\left((\mathrm{Mn}, \mathrm{Fe})_{2} \mathrm{O}_{3}\right)$, hematite $\left(\mathrm{Fe}_{2} \mathrm{O}_{3}\right)$ and carbonates $\left((\mathrm{Mg}, \mathrm{Ca}) \mathrm{CO}_{3}\right)$, whereas Comi$\log$ is mineralogically dominated by pyrolusite $\left(\mathrm{MnO}_{2}\right)$, nsutite $\left(\mathrm{Mn}_{1-x}^{4+} \mathrm{Mn}_{2-2 x}^{2+}(\mathrm{OH})_{2 x}\right)$ and cryptomelane $\left(\mathrm{KMn}_{8} \mathrm{O}_{16}\right)$ and exhibits a relatively high level of microporosity. ${ }^{[2]}$ The ores were ground and sieved into particle size fractions of 9.5 to $16 \mathrm{~mm}$. The ores were chemically analyzed by SINTEF Norlab using X-ray fluorescence, while the oxygen amount connected to Mn-oxides was obtained by titration for ore, whereas Eltra (combustion-IR) was used to determine the amount of carbon, which was recalculated to $\mathrm{CO}_{2}$ in the carbonate minerals. Comilog ore contains a high alumina content, whereas Assmang ore contains a high iron content. Comilog ore has the highest manganese to iron ratio and oxygen level, i.e., oxygen to manganese ratio $\left(x\right.$ in $\mathrm{MnO}_{x}$ ), at approximately 1.9 compared to 1.5 for Assmang ore. The uncertainty of the permanganometric titration used to measure the oxygen level in the ores is 10 pct. Assmang ore has a much higher basicity, given by the ratio (wt pet $\mathrm{MgO}+$ wt pet $\mathrm{CaO}) /($ wt pet $\mathrm{SiO}_{2}+$ wt pet $\mathrm{Al}_{2} \mathrm{O}_{3}$ ). A metallurgical coke originating from Poland was used as reductant. The bulk chemical composition of all raw materials on a dry basis is summarized in Table I.

\section{B. Experimental Procedure}

A 75-kVA open induction furnace was used to investigate the smelting and reduction of Comilog and Assmang ores in a setup which simulates the industrial high carbon ferromanganese furnace. The induction furnace used has an induction coil of a total height of $310 \mathrm{~mm}$ from the bottom, and the interior of the furnace chamber is refractory lined. During induction coil heating, a temperature gradient develops with the highest temperature at the bottom of the furnace with decreasing temperature towards the furnace top. This simulates the interior temperature profile of an industrial ferromanganese furnace. Graphite crucibles of 150 
Table I. Bulk Chemical Composition of Ores and Calculated Composition Assuming Complete Prereduction to MnO and FeO (Oxygen Related to Mn Oxides is Distributed to $\mathrm{MnO}$ and $\mathrm{MnO}_{2}$, Where the Calculated Amount of $\mathrm{MnO}_{2}$ is $\mathrm{Shown} \mathrm{CO}_{2}$ is $\mathrm{CO}_{2}$ in Carbonates, and the Iron is Assumed to be $\mathrm{Fe}_{2} \mathrm{O}_{3}$ )

\begin{tabular}{|c|c|c|c|c|c|c|}
\hline \multicolumn{4}{|c|}{ Raw Materials Bulk Composition (Dry Basis), Wt Pct } & \multicolumn{3}{|c|}{ Manganese Sources After Prereduction (Calculated Composition) } \\
\hline Components & Comilog & Assmang & Polish coke & Components & Comilog & Assmang \\
\hline $\mathrm{MnO}_{2}$ & 74.8 & 37.4 & & $\mathrm{MnO}$ & 83.2 & 70.1 \\
\hline $\mathrm{Mn}$ & 51.8 & 46.0 & & $\mathrm{FeO}$ & 4.7 & 13.9 \\
\hline $\mathrm{Fe}$ & 3.03 & 9.04 & & $\mathrm{SiO}_{2}$ & 4.2 & 5.0 \\
\hline $\mathrm{SiO}_{2}$ & 4.03 & 4.20 & 5.44 & $\mathrm{Al}_{2} \mathrm{O}_{3}$ & 7.3 & 0.5 \\
\hline $\mathrm{Al}_{2} \mathrm{O}_{3}$ & 4.80 & 0.38 & 3.57 & $\mathrm{CaO}$ & 0.5 & 8.8 \\
\hline $\mathrm{K}_{2} \mathrm{O}$ & 0.82 & 0.10 & 0.29 & $\mathrm{MgO}$ & 0.1 & 1.7 \\
\hline $\mathrm{CaO}$ & 0.72 & 7.51 & 0.37 & $\mathrm{~B}^{*}$ & 0.1 & 1.9 \\
\hline $\mathrm{MgO}$ & 0.17 & 1.3 & 0.23 & & & \\
\hline $\mathrm{BaO}$ & 0.17 & 0.7 & 0.03 & & & \\
\hline $\mathrm{P}$ & 0.08 & 0.03 & 0.06 & & & \\
\hline $\mathrm{S}$ & 0.01 & 0.15 & 0.56 & & & \\
\hline $\mathrm{CO}_{2}$ & 0.15 & 3.7 & & & & \\
\hline Fix $C$ & - & & 88.4 & & & \\
\hline $\mathrm{Mn} / \mathrm{Fe}$ & 17.08 & 5.1 & & & & \\
\hline
\end{tabular}

$* \mathrm{~B}=(\mathrm{CaO}+\mathrm{MgO}) /\left(\mathrm{SiO}_{2}+\mathrm{Al}_{2} \mathrm{O}_{3}\right)$

$\mathrm{mm}$ outer diameter, $115 \mathrm{~mm}$ inner diameter, $400 \mathrm{~mm}$ outer height and approximately $380 \mathrm{~mm}$ inner depth were used to contain the raw materials and act as a heating element in the induction furnace. The raw materials in each experiment were stratified as layers into the graphite crucible and consisted of a $100-\mathrm{mm}$ coke layer in the bottom of the crucible working as the coke bed in an industrial furnace, a 200-mm ore layer placed on top of the coke bed, and, lastly, a 50-mm coke layer on the top of the ore working as insulation and inhibiting charge re-oxidation. Figure 1 shows a sketch of the induction furnace and graphite crucible containing the raw materials.

The furnace crucible was heated gradually at $25^{\circ} \mathrm{C}$ per minute up from $298 \mathrm{~K}\left(25^{\circ} \mathrm{C}\right)$ to $1473 \mathrm{~K}\left(1200^{\circ} \mathrm{C}\right)$ on top of the coke bed, where it was held at constant temperature for $30 \mathrm{~min}$ to ensure complete ore prereduction before the last heating step. Final target temperatures were $1473 \mathrm{~K}\left(1200{ }^{\circ} \mathrm{C}\right), 1673 \mathrm{~K}(1400$ $\left.{ }^{\circ} \mathrm{C}\right)$ and $1773 \mathrm{~K}\left(1500{ }^{\circ} \mathrm{C}\right)$ on top of the coke bed. Heating to target temperatures was done at $20^{\circ} \mathrm{C}$ per minute. Experiments were conducted at different coke bed temperatures to investigate the temperature dependence on melting and reduction. At the end of each experiment, the furnace was shut down and the crucible was cooled for 24 hours. After cooling the crucible was filled with epoxy, and the crucible was cut vertically in the middle. Melted and reduced ore samples were core-drilled out from selected areas close to the coke bed and further studied using an electron probe microanalyzer (EPMA) coupled with wavelength-dispersive spectrometry (WDS).

During each experiment, temperature in the crucible was measured using two type $\mathrm{C}$ tungsten/rhenium thermocouples encapsulated by alumina and graphite insulation tubes. As shown in Figure 1, the control thermocouple was located at the top of the coke bed

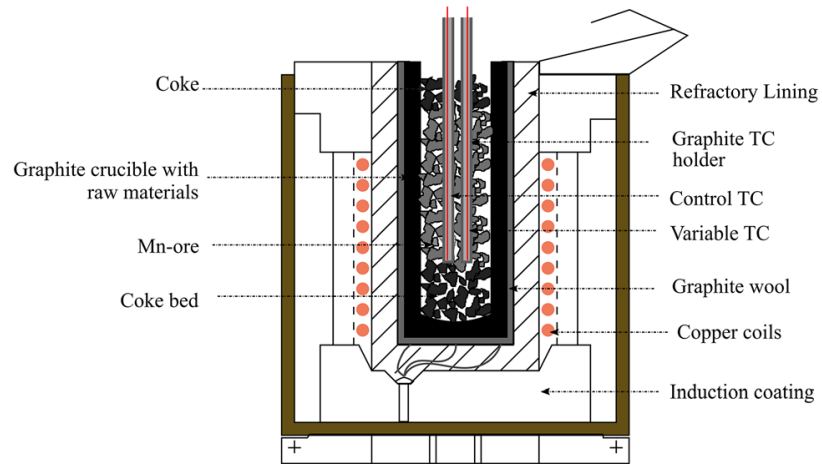

Fig. 1-Sketch of induction furnace and graphite crucible containing raw materials.

(fixed position) and gives the reference temperature measurement. Likewise, the variable thermocouple, initially positioned on top of the coke bed, was used to measure temperatures at $20-\mathrm{mm}$ interval distances away from the coke bed up to the top of the charge, thus establishing the temperature gradient of the system. Stable temperatures at each point were established by holding the thermocouple fixed at that position for 3 min. The stable temperature at each $20-\mathrm{mm}$ interval distance was measured in two runs, i.e., away from the coke bed and towards the coke bed, while maintaining a constant target coke bed temperature for $60 \mathrm{~min}$. The typical temperature gradients shown in Figure 2 were measured while maintaining constant coke bed temperatures at $1473 \mathrm{~K}\left(1200{ }^{\circ} \mathrm{C}\right), 1673 \mathrm{~K}\left(1400{ }^{\circ} \mathrm{C}\right)$ and 1773 $\mathrm{K}\left(1500{ }^{\circ} \mathrm{C}\right)$. The gradient simulating conditions of the SAF process are approximately in the range of 27 to 35 ${ }^{\circ} \mathrm{C}$ per $\mathrm{cm}$ vertically across the charge material, and the variations at constant setpoint are approximately \pm 20 ${ }^{\circ} \mathrm{C}$ in the center of the crucible. 


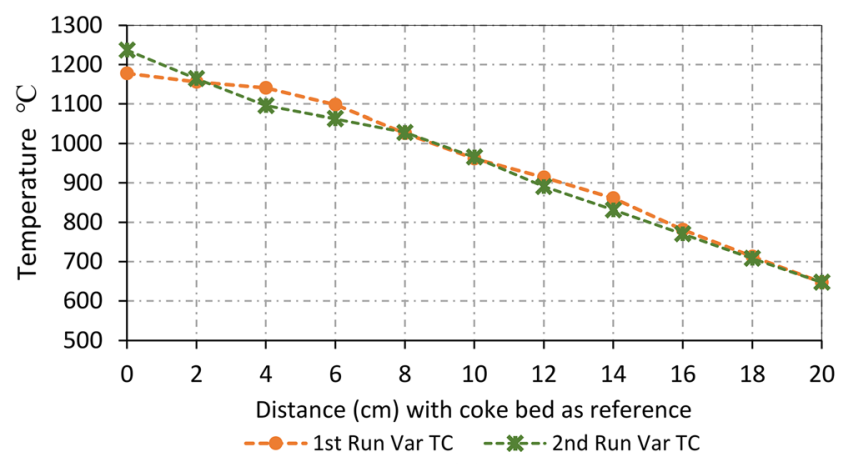

(a)

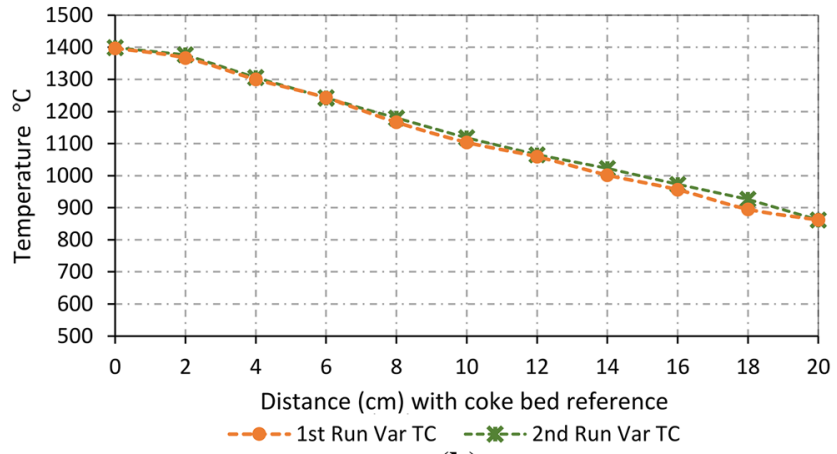

(b)

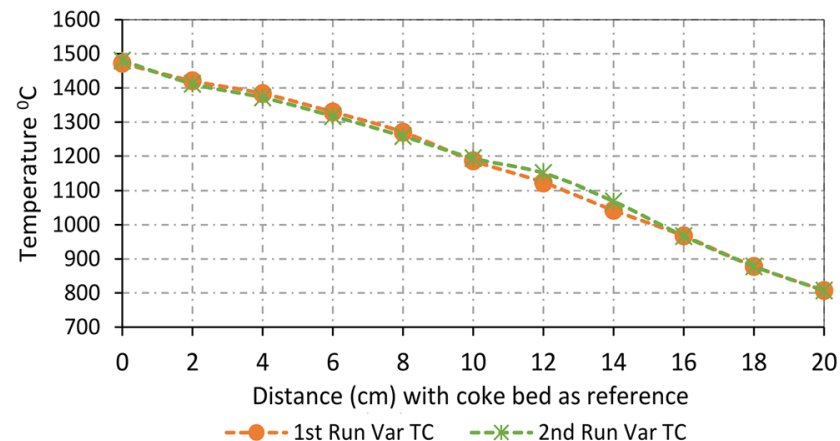

(c)

Fig. 2-Typical temperature gradient profiles established while maintaining constant coke bed temperatures at $(a) 1473 \mathrm{~K}\left(1200{ }^{\circ} \mathrm{C}\right),(b) 1673 \mathrm{~K}$ $\left(1400{ }^{\circ} \mathrm{C}\right)$ and $(c) 1773 \mathrm{~K}\left(1500{ }^{\circ} \mathrm{C}\right)$.

\section{Sampling and Characterization}

Melted and reduced ore samples with a diameter of 20 $\mathrm{mm}$ were core-drilled out from selected areas close to the coke bed at temperatures $>1373 \mathrm{~K}\left(1100{ }^{\circ} \mathrm{C}\right)$. In this study, slag samples will be named according to manganese ore abbreviated as CM and AS for Comilog and Assmang slag samples, respectively. Prior to EPMA analysis, metallographic sample preparation and polishing were conducted to produce smooth surfaces. Samples were embedded using epoxy resin curing for 12 hours, and the surfaces of the samples were initially ground using $\mathrm{SiC}$ grinding paper, grit 220, before polishing using polyurethane-based pads as the polishers (i.e., MD-Dac, $200 \mathrm{~mm}$, and MD-Nap, $300 \mathrm{~mm}$ ) and an abrasive suspension, diamond water-based type, as the polishing agent, gradually decreased from 9,3 and $1 \mu \mathrm{m}$ particle size. The polished samples were cleaned by tap water using a cotton swab and dried in an oven for 12 hours. After metallographic preparation, a high-resolution electron probe micro-analyzer (EPMA) JEOL JXA 8500TM supported by wavelength-dispersive spectroscopy (WDS) was used. EPMA provides high accuracy on quantitative analysis of the elements in observed phases of the samples and can also be used for imaging. On each of the observed phases of the core-drilled samples, three points were analyzed, and backscattered images of the analyzed samples were recorded. Post-processing of the backscattered images was done using Image $^{\circledR}{ }^{\circledR}$ software to quantify the phase distribution of different phases based on their contrast threshold; subsequently, the overall composition of liquid phase based on phase area fraction and chemical analyses was calculated. The accuracy of the EPMA measurements was within \pm 1 wt pet.

\section{Equilibrium Calculations}

FactSage 7.3 thermochemical software ${ }^{[30]}$ was used to calculate equilibrium phases in the reduction process of Comilog and Assmang ores. The equilibrium module in FactSage 7.3 was used to calculate the equilibrium phase relations in the system $\mathrm{MnO}-\mathrm{SiO}_{2}-\mathrm{Al}_{2} \mathrm{O}_{3}-\mathrm{FeO}-$ $\mathrm{CaO}-\mathrm{MgO}$ for Comilog and Assmang mixed with excess carbon in a carbon monoxide (CO) atmosphere as a function of temperature in the range $1373 \mathrm{~K}$ to $1873 \mathrm{~K}\left(1100{ }^{\circ} \mathrm{C}\right.$ to $\left.1600{ }^{\circ} \mathrm{C}\right)$ at intervals of $323 \mathrm{~K}(50$ ${ }^{\circ} \mathrm{C}$ ) and atmospheric pressure set to $1 \mathrm{~atm}$. In addition, phase distribution was calculated in the absence of carbon reductant for the temperature range $1373 \mathrm{~K}$ to $2273 \mathrm{~K}\left(1100{ }^{\circ} \mathrm{C}\right.$ to $\left.2000{ }^{\circ} \mathrm{C}\right)$. The FactPS, FToxid and FTmisc databases were used in all calculations. The six-component oxide compositions for Comilog and Assmang ores were calculated by mass balance assuming higher oxides of manganese and iron to be pre-reduced down to $\mathrm{MnO}$ and $\mathrm{FeO}$, respectively, and all other oxides $\left(\mathrm{SiO}_{2}, \mathrm{Al}_{2} \mathrm{O}_{3}, \mathrm{CaO}\right.$ and $\left.\mathrm{MgO}\right)$ remained unreacted. The calculated oxide compositions of the pre-reduced Comilog and Assmang ores are as shown in Table I and were used as starting input values for equilibrium calculations. 


\section{RESULTS}

Higher manganese oxides are pre-reduced to manganese monoxide, and iron oxides are reduced to metallic iron and wustite at a temperature of $1473 \mathrm{~K}$ $\left(1200{ }^{\circ} \mathrm{C}\right) \cdot{ }^{[1]}$ In this work, Comilog and Assmang slag samples at temperatures $>1473 \mathrm{~K}\left(1200{ }^{\circ} \mathrm{C}\right)$ from a setup which simulates the SAF have been studied to show phase development during the formation and reduction of slag from the high-temperature regions of the furnace. The results are presented in this section.

\section{A. Phase Development and Reduction of Comilog Ore}

Typical microstructures of Comilog slags CM-1, CM-2, CM-3 and CM-4 from the top of the coke bed at temperatures $1490 \mathrm{~K}\left(1217^{\circ} \mathrm{C}\right), 1550 \mathrm{~K}\left(1277{ }^{\circ} \mathrm{C}\right)$, $1683 \mathrm{~K}\left(1410{ }^{\circ} \mathrm{C}\right)$ and $1748 \mathrm{~K}\left(1475{ }^{\circ} \mathrm{C}\right)$, respectively, show a variety of phases as observed using backscattered electron images shown in Figure 3.
Comilog slags CM-1, CM-2 and CM-3 in Figure 3 show the microstructure of slag samples containing spherical manganosite $(\mathrm{MnO})$ phases and the co-existence of a medium gray matrix, which is tephroite $\left(2 \mathrm{MnO} \cdot \mathrm{SiO}_{2}\right)$ phase, a dark gray galaxite $\left(\mathrm{MnO} \cdot \mathrm{Al}_{2} \mathrm{O}_{3}\right)$ phase and bright alloy phase. At high temperatures it is believed that the slag will be a mixture of the spherical manganosite phase in coexistence with liquid, where the liquid has precipitated to the tephroite and galaxite phase as will be discussed later. However, for slag CM-4, the spherical MnO phase has been completely dissolved. Some dendrites have precipitated during cooling, and a large region of $\mathrm{MnO}$ depleted slag is observed. The composition of the alloy phase varies considerably as size increases, with the $\mathrm{Mn} / \mathrm{Fe}$ ratios increasing with increase in alloy particle size. The observed $\mathrm{Mn} / \mathrm{Fe}$ ratios for the Comilog experiments were on average approximately $0.04,0.96$ and 12.1 for the metal prills $(<$ $10 \mu \mathrm{m})$, beads $(10-100 \mu \mathrm{m})$ and bulk phase $(>100 \mu \mathrm{m})$, respectively. Details of the compositions of the phases in

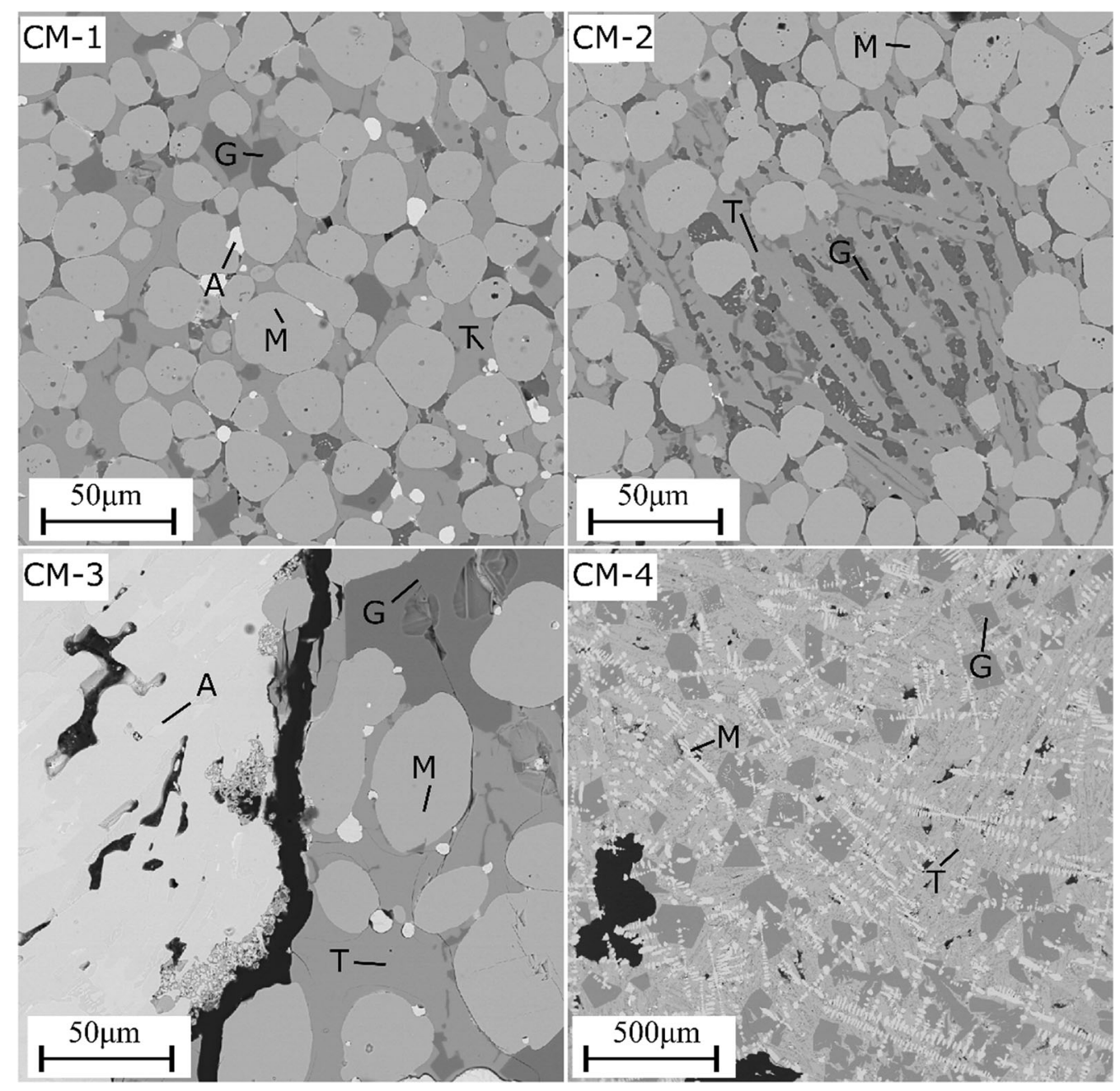

Fig. 3-BSE images of Comilog slag samples CM-1, CM-2, CM-3 and CM-4 collected from positions on top of the coke with temperatures 1490 $\mathrm{K}\left(1217^{\circ} \mathrm{C}\right), 1550 \mathrm{~K}\left(1277^{\circ} \mathrm{C}\right), 1683 \mathrm{~K}\left(1410^{\circ} \mathrm{C}\right)$ and $1748 \mathrm{~K}\left(1475^{\circ} \mathrm{C}\right)$, respectively. $\mathrm{A}=$ alloy, $\mathrm{M}=$ monoxide; $\mathrm{T}=$ tephroite, $\mathrm{G}=$ galaxite. 
these slag samples are given in Table II, as determined by wavelength-dispersive spectroscopy (WDS) in EPMA. The accuracy of the EPMA measurements was within \pm 1 wt pet; as such, phases containing maximum concentrations $<1 \mathrm{wt}$ pet of a particular component do not exhibit solid solution with that particular component since these concentrations are below the limits of uncertainty of the measurements and are thus negligible. Therefore, galaxite $\left(\mathrm{MnO} \cdot \mathrm{Al}_{2} \mathrm{O}_{3}\right)$ and pure manganosite (MnO-monoxide) phases, for example, do not exhibit solid solution with $\mathrm{SiO}_{2}$. This can be also be seen from the $\mathrm{MnO}-\mathrm{Al}_{2} \mathrm{O}_{3}-\mathrm{SiO}_{2}$ ternary phase diagram. ${ }^{[31]}$

Figure 4 shows the BSE micrographs for Comilog slags CM-5 and CM-6 taken from $5 \mathrm{~cm}$ below the top of the coke bed, with reference coke bed temperatures at $1683 \mathrm{~K}\left(1410{ }^{\circ} \mathrm{C}\right)$ and $1748 \mathrm{~K}\left(1475^{\circ} \mathrm{C}\right)$, respectively. As can be seen in the micrographs, slags CM-5 and CM-6 did not contain any solid $\mathrm{MnO}$, i.e., all the solid $\mathrm{MnO}$ has dissolved into the liquid phase upon reduction. The total $\mathrm{MnO}$ content of the liquid slag was approximately $45.5 \mathrm{wt}$ pct and $52.1 \mathrm{wt}$ pct, respectively. The phases in the slags are mainly close to tephroite phase and galaxite phase, and their compositions are shown in Table II. The bulk alloy phase was mainly manganese with $\mathrm{Mn}$ / Fe ratios at 11.7 and 9.7, respectively, for slags CM-5 and CM-6. Details of the composition of the liquid phase calculated based on area fraction and composition of the phases are shown in Table III.

\section{B. Phase Development and Reduction for Assmang Ore}

Figure 5 shows typical microstructure for Assmang slags AS-1, AS-2, AS-3 and AS-4 from the top of the coke bed at temperatures $1493 \mathrm{~K}\left(1220{ }^{\circ} \mathrm{C}\right), 1543 \mathrm{~K}$ $\left(1270{ }^{\circ} \mathrm{C}\right), 1686 \mathrm{~K}\left(1413{ }^{\circ} \mathrm{C}\right)$ and $1778 \mathrm{~K}\left(1505{ }^{\circ} \mathrm{C}\right)$, respectively.

The microstructure of these slag samples consists of spherical manganosite $(\mathrm{MnO})$ phases in co-existence with a gray slag matrix made up of mainly $\mathrm{MnO}, \mathrm{CaO}$ and $\mathrm{SiO}_{2}$. The gray slag matrix is believed to be liquid at high temperatures as will be discussed later. The bright phase is the alloy produced. Details of the compositions of the phases in these slag samples as measured in EPMA are given in Table IV. The composition of the alloy phase varies considerably as size increases, with the $\mathrm{Mn} / \mathrm{Fe}$ ratios increasing with an increase in alloy particle size. The observed $\mathrm{Mn} / \mathrm{Fe}$ ratios for the Assmang samples were on average approximately $0.04,3.75$ and 11.14 for the metal prills $(<10 \mu \mathrm{m})$, beads (10 to 100 $\mu \mathrm{m})$ and bulk phase $(>100 \mu \mathrm{m})$, respectively.

BSE images of Assmang slag AS-5 collected from positions $5 \mathrm{~cm}$ below the top of the coke bed with reference coke bed temperature at $1778 \mathrm{~K}\left(1505{ }^{\circ} \mathrm{C}\right)$ presented in Figure 6 showing two distinct phases on higher magnification: a light gray phase and a dark gray slag matrix. MnO spheres have been completely dissolved, and the LG and DG phases have precipitated during cooling. A large region of $\mathrm{MnO}$ depleted slag is observed. Details of the composition of the phases in these slag samples as measured in EPMA are given in Table IV, and the liquid phase calculated based on area fraction and composition of the phases for Assmang slag samples is shown in Table V. The monoxide phase contains up to $10 \mathrm{wt}$ pct $\mathrm{FeO}$, which is quite unexpected and will be discussed further.

Phase development and reduction of Comilog and Assmang ores show that the solid MnO phase will be present in the slag on top of the coke bed and the slag will hence not flow into the coke bed until the solid spherical $\mathrm{MnO}$ is dissolved. For the basic Assmang slag this will happen between 49 to 17 wt pet $\mathrm{MnO}$ in the slag phase and 62 to $45.5 \mathrm{wt}$ pet $\mathrm{MnO}$ in the slag phase for the acidic Comilog ore. The amount of monoxide phase is dependent on temperature and basicity of ore. Assmang ore behaves as a fluid at a higher temperature compared to Comilog due to a higher number of basic oxides, and hence a higher quantity of solid monoxide spheres. The alloy composition is also seen to vary considerably with size, where the larger alloy particles had a $\mathrm{Mn} / \mathrm{Fe}$ ratio of 12.1 and 11.1 for Comilog and Assmang, respectively. The $\mathrm{Mn} / \mathrm{Fe}$ ratio in the Assmang experiment is much larger than the theoretical one, which is about 5.1. This can be due to the heterogeneity in the sample as well as that some of the iron is still as $\mathrm{FeO}$ as seen in Table IV.

\section{Calculated Equilibrium Phases During Reduction of Comilog and Assmang}

The calculated equilibrium phase distribution for the pre-reduced ore compositions of Comilog and Assmang (listed in Table I) for temperatures $1373 \mathrm{~K}$ to $1873 \mathrm{~K}$ $\left(1100{ }^{\circ} \mathrm{C}\right.$ to $1600^{\circ} \mathrm{C}$ ) are shown in Figures 7 (a) through (d).

Figure 7(a) shows phase distribution in primary slag, and Figure 7(b) shows the phase distribution upon heating and reduction of Comilog ore. Four phases, namely, monoxide (( $\mathrm{Mn}, \mathrm{Fe}, \mathrm{Mg}) \mathrm{O})$, liquid slag, olivine $\left((\mathrm{Mn}, \mathrm{Mg}, \mathrm{Ca})_{2} \mathrm{SiO}_{4}\right)$ and spinel $\left.(\mathrm{Mn}, \mathrm{Mg}) \mathrm{Al}_{2} \mathrm{O}_{4}\right)$, are shown to vary with increasing temperature in a non-reducing environment in the primary slag. The solid monoxide phase completely dissolves into liquid slag at about $2023 \mathrm{~K}\left(1750{ }^{\circ} \mathrm{C}\right)$. Figure 7 (b) shows the phase distribution during the carbothermic reduction of Comilog. At $1373 \mathrm{~K}\left(1100{ }^{\circ} \mathrm{C}\right)$, three major phases are observed, namely, monoxide phase ((Mn,Fe,Mg)O), olivine ((Mn, $\mathrm{Mg}, \mathrm{Ca})_{2} \mathrm{SiO}_{4}$-predominantly tephroite at 89 wt pet $\mathrm{Mn}_{2} \mathrm{SiO}_{4}$ ), and spinel (predominantly galaxite phase- $\mathrm{MnAl}_{2} \mathrm{O}_{4}$ ), and a liquid slag started to form at approximately $1423 \mathrm{~K}\left(1150^{\circ} \mathrm{C}\right)$. Alloy is formed during slag reduction, and the solid monoxide phase completely dissolves into liquid slag at about $1623 \mathrm{~K}\left(1350{ }^{\circ} \mathrm{C}\right)$.

Figures 7(c) and (d) shows the phase distribution with increase in temperature in the primary slag and under reducing environment (i.e., in the presence of solid carbon), respectively, for Assmang ore. Figure 7(c) shows that a liquid slag is formed during heating of Assmang ore with corresponding dissolution of olivine $\left((\mathrm{Mn}, \mathrm{Mg}, \mathrm{Ca})_{2} \mathrm{SiO}_{4}\right)$, spinel $\left.(\mathrm{Mn}, \mathrm{Mg}) \mathrm{Al}_{2} \mathrm{O}_{4}\right)$ and monoxide $((\mathrm{Mn}, \mathrm{Fe}, \mathrm{Mg}) \mathrm{O})$. The monoxide phase completely dissolves in the liquid slag at about $2173 \mathrm{~K}\left(1900{ }^{\circ} \mathrm{C}\right)$. However, when Assmang is in equilibrium with solid carbon (Figure 7(d)), the monoxide phase is present throughout the temperature range with much of its dissolution occurring up to $1723 \mathrm{~K}\left(1450{ }^{\circ} \mathrm{C}\right)$. 
Table II. Summary of the Average Compositions of the Phases Experimentally Observed From Comilog Slags (CM-1)-(CM-4) From Top of the Coke Bed; (CM-5)-(CM-6) are $5 \mathrm{~cm}$ Into the Coke Bed

\begin{tabular}{|c|c|c|c|c|c|c|c|c|c|}
\hline \multirow[b]{2}{*}{ Identified Phase } & \multirow[b]{2}{*}{ Sample Name } & \multirow{2}{*}{$\begin{array}{c}\text { Temperature } \\
\mathrm{K}\left({ }^{\circ} \mathrm{C}\right)\end{array}$} & \multirow[b]{2}{*}{$\mathrm{MnO}$} & \multicolumn{3}{|c|}{ Wt Pct } & \multirow[b]{2}{*}{$\mathrm{CaO}$} & \multirow[b]{2}{*}{$\mathrm{FeO}$} & \multirow{2}{*}{ Total } \\
\hline & & & & $\mathrm{SiO}_{2}$ & $\mathrm{Al}_{2} \mathrm{O}_{3}$ & $\mathrm{MgO}$ & & & \\
\hline \multirow[t]{4}{*}{ Manganosite } & CM-1 & $1490(1217)$ & 100.4 & 0.10 & 0.17 & 0.28 & 0.01 & 0.58 & 101.5 \\
\hline & CM-2 & $1550(1277)$ & 97.8 & 0.13 & 0.19 & 0.13 & - & 4.02 & 102.3 \\
\hline & CM-3 & $1683(1410)$ & 100.9 & 0.10 & 0.34 & 0.40 & 0.02 & 0.24 & 102.0 \\
\hline & CM-4 & $1748(1475)$ & 94.4 & 0.35 & 0.29 & 0.20 & 0.04 & 0.22 & 95.5 \\
\hline \multirow[t]{6}{*}{ Tephroite } & CM-1 & $1490(1217)$ & 70.2 & 27.0 & 0.90 & 0.53 & 0.22 & 0.35 & 99.2 \\
\hline & CM-2 & $1550(1277)$ & 69.3 & 27.6 & 0.94 & 0.24 & 0.12 & 1.53 & 99.7 \\
\hline & CM-3 & $1683(1410)$ & 70.4 & 27.5 & 0.71 & 0.56 & 0.45 & 0.16 & 99.8 \\
\hline & CM-4 & $1748(1475)$ & 65.3 & 30.0 & 0.65 & 0.35 & 0.35 & 0.14 & 96.8 \\
\hline & CM-5 & $>1683(1410)$ & 52.8 & 30.6 & 11.7 & 0.18 & 0.89 & 0.21 & 96.4 \\
\hline & CM-6 & $>1748(1475)$ & 61.7 & 30.0 & 1.07 & 0.28 & 2.81 & 0.22 & 96.1 \\
\hline \multirow[t]{6}{*}{ Galaxite } & CM-1 & $1490(1217)$ & 41.1 & 0.18 & 58.5 & 1.16 & - & 0.36 & 101.3 \\
\hline & CM-2 & $1550(1277)$ & 41.4 & 0.28 & 57.6 & 0.29 & 0.01 & 0.16 & 99.7 \\
\hline & CM-3 & $1683(1410)$ & 41.1 & 0.10 & 60.0 & 1.37 & 0.02 & 0.12 & 102.7 \\
\hline & CM-4 & $1748(1475)$ & 37.6 & 0.20 & 57.7 & 0.99 & 0.01 & 0.08 & 96.6 \\
\hline & CM-5 & $>1683(1410)$ & 40.2 & 0.42 & 58.6 & 1.43 & 0.04 & 0.15 & 100.8 \\
\hline & CM-6 & $>1748(1475)$ & 33.5 & 0.09 & 60.5 & 3.26 & 0.02 & 0.14 & 97.5 \\
\hline
\end{tabular}

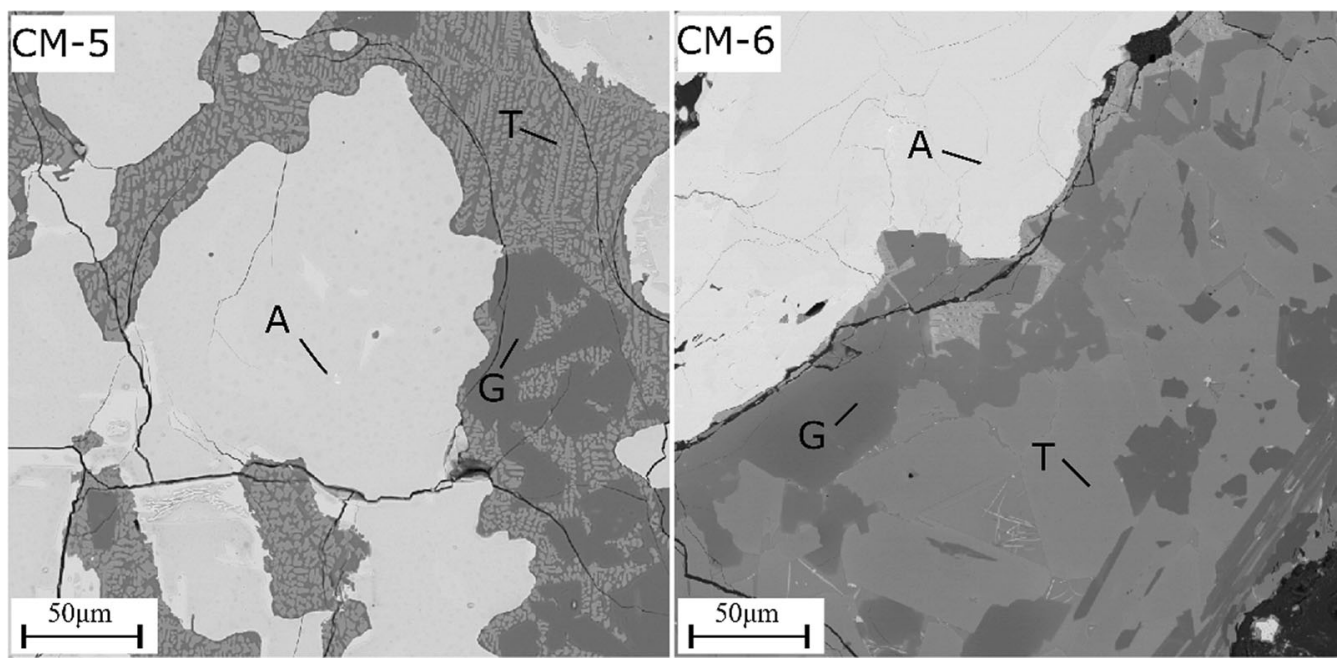

Fig. 4-BSE images of Comilog slags CM-5 and CM-6 collected from positions $5 \mathrm{~cm}$ below the top of the coke with reference coke bed temperatures at $1683 \mathrm{~K}\left(1410^{\circ} \mathrm{C}\right)$ and $1748 \mathrm{~K}\left(1475^{\circ} \mathrm{C}\right)$, respectively. $\mathrm{A}=$ alloy, $\mathrm{T}=$ tephroite, $\mathrm{G}=$ galaxite.

This monoxide phase is predominantly $\mathrm{MnO}$ in the temperature range $1373 \mathrm{~K}\left(1100{ }^{\circ} \mathrm{C}\right)$ to $1573 \mathrm{~K}\left(1300{ }^{\circ} \mathrm{C}\right)$, and the composition changes with more $\mathrm{MgO}$ dissolving in the monoxide solid solution as presented in Table IV.

Tables VI and VII respectively show the chemical compositions of liquid slag and alloy formed during the reduction smelting of pre-reduced Comilog and Assmang in the temperature range of $1373 \mathrm{~K}$ to $1873 \mathrm{~K}$ $\left(1100{ }^{\circ} \mathrm{C}\right.$ to $\left.1600{ }^{\circ} \mathrm{C}\right)$.

\section{DISCUSSION}

The phase development and reduction of slag from Comilog and Assmang ores as a function of temperature and in relation to position within the coke bed are discussed based on metallographic observations in
EPMA, phase compositions measured by WDS and FactSage 7.3-based thermodynamic equilibrium calculations.

\section{A. Monoxide Phase Development and its Dissolution in Slag}

The presence of a solid phase in coexistence with the liquid slag phase is important during the production of Mn ferroalloys as it will both explain the high $\mathrm{MnO}$ activity in the slag and also affect the viscosity of the slag. A special focus will hence be given to the monoxide phase development. Comilog slag samples CM-1 to CM-4 in Figure 3 show a considerable decrease in the fraction of solid monoxide phases on top of the coke bed as the reduction proceeds. Slags CM-1 to CM-3 show that a liquid slag coexists with solid $\mathrm{MnO}$ phase in the 
temperature range $1490 \mathrm{~K}$ to $1683 \mathrm{~K}\left(1217{ }^{\circ} \mathrm{C}\right.$ to 1410 ${ }^{\circ} \mathrm{C}$ ), and slag CM-5 shown in Figure 4 shows a slag which has been completely liquid at $5 \mathrm{~cm}$ below the top of coke bed. The solidified slags CM-5 and CM-6 in Figure 4 showed a relatively homogeneous slag phase with no $\mathrm{MnO}$ dendrites. This shows that liquid slag from Comilog flows into the coke bed at temperatures close to $1683 \mathrm{~K}\left(1410{ }^{\circ} \mathrm{C}\right)$, and it is in close agreement with the complete dissolution temperature for the monoxide phase presented in Table VI from FactSage calculations. Based on the same analysis, Assmang slag AS-5 in Figure 6 is observed inside the coke bed, $5 \mathrm{~cm}$ below the top of coke bed at a higher temperature of $1778 \mathrm{~K}\left(1505^{\circ} \mathrm{C}\right)$ compared to Comilog. This is mainly due to the presence of solid monoxide phase in Assmang, which makes the slag viscous. The dissolution of solid monoxide phase to a point where only dissolved $\mathrm{MnO}$ remains in the liquid slag phase has been previously reported by Tangstad and Olsen to slow down the kinetics of the reduction reaction. ${ }^{[26]}$ This is mainly because of the drop in the chemical potential difference that drives the rate of reduction, which is a consequence of the drop in the activity of $\mathrm{MnO}$. Comilog will hence be reduced at lower temperatures because of a higher reduction rate compared to Assmang ore. The reduction rate for Comilog ore will however decrease faster than that of the Assmang ore when solid monoxide is dissolved.

Thermodynamic analysis of the phase development in the primary slag is presented in Figure 7 . The change from solid to liquid is dependent on temperature as well as the chemical composition of the pre-reduced ore. Comilog has higher primary liquid slag formation per unit temperature compared to Assmang, and the monoxide phases in Comilog completely dissolve in liquid at $2023 \mathrm{~K}\left(1750{ }^{\circ} \mathrm{C}\right)$, which is lower than $2173 \mathrm{~K}$ $\left(1900{ }^{\circ} \mathrm{C}\right)$ for Assmang as presented in Figures 7(a) and (c), respectively.

During carbothermic reduction, the initial slag formation temperature is lower for Comilog compared to Assmang as presented in Table VI. However, the dissolution of the monoxide solid solution is dependent on the composition of the ore and charge mixture as previously reported. ${ }^{[25-27]}$ Comilog ore has negligible $\mathrm{MgO}$ content (Table I), and as such it forms a monoxide phase, which is purely $\mathrm{MnO}$, as shown in FactSage calculated values presented in Table VIII, which are in close agreement with experimental values in Table II. This monoxide solid solution phase in Comilog completely dissolves in the liquid phase at $1623 \mathrm{~K}\left(1350{ }^{\circ} \mathrm{C}\right)$ as shown in Figure 7(b). In contrast to Comilog, the monoxide solution phase in Assmang does not dissolve completely in slag as shown in Figure 7(d). The difference in solid monoxide phase chemistry shows that Assmang forms a monoxide ( $\mathrm{Mn}, \mathrm{Mg}) \mathrm{O}$ solid solution, which becomes more enriched in $\mathrm{MgO}$ with increases in temperature as presented in Table VIII. As shown in Figure 7(d), much of the monoxide dissolution in slag for Assmang occurs up to $1723\left(1450{ }^{\circ} \mathrm{C}\right)$, after which the monoxide is enriched in $\mathrm{MgO}$. Experimentally, the monoxide phase in Assmang exhibits $\mathrm{MgO}$ enrichment, however not to the same level as values thermodynamically calculated in FactSage 7.3. In addition, the chemistry of the monoxide phase in Assmang shows significantly higher $\mathrm{FeO}$ contents compared to predicted values in FactSage 7.3. The most probable explanation for this inconsistency is that iron oxides are reduced down to $\mathrm{FeO}$ instead of $\mathrm{Fe}$ because of lower $\mathrm{CO}$ gas concentrations in this experimental setup. As such, $\mathrm{FeO}$ becomes stabilized in the monoxide solid solution. Contrastingly, previous studies ${ }^{[25,26,28]}$ conducted in a relatively high and constant $\mathrm{CO}$ gas flow have shown the solid monoxide phase to be pure $\mathrm{MnO}$ or $(\mathrm{Mn}, \mathrm{Mg}) \mathrm{O}$ solid solution.

Therefore, based on monoxide phase dissolution into slag, Comilog is expected to be fluid enough to percolate through the coke bed at temperatures $>1673\left(1400{ }^{\circ} \mathrm{C}\right)$ compared to Assmang, which has a considerable quantity of solid monoxide spheres. This implies that Assmang ore will behave as a fluid at a higher temperature compared to Comilog because of a higher amount of basic oxides and hence a higher quantity of solid monoxide spheres. The dissolution and slag reduction behavior of Comilog and Assmang agrees with findings in earlier works, ${ }^{[1-20]}$ where materials with higher acid oxides (e.g., Comilog ore) melt and reduce at a lower temperature than materials with higher basic oxides (e.g., Assmang).

\section{B. Slag Reduction Path}

The compositions of the liquid slag in coexistence with the solid monoxide phase and after complete dissolution for Comilog and Assmang have been presented in Tables III and V, respectively. Before the reduction commences, the primary slags show a liquid slag in co-existence with solid $\mathrm{MnO}$. In the temperature range $1683 \mathrm{~K}$ to $1748 \mathrm{~K}\left(1410{ }^{\circ} \mathrm{C}\right.$ to $\left.1475{ }^{\circ} \mathrm{C}\right)$, the reduction of the primary slag from Comilog ore will take place from about $85 \mathrm{wt}$ pct $\mathrm{MnO}$ in the presence of two stable phases, manganosite + liquid slag down to the liquidus composition of about $63 \mathrm{wt}$ pet $\mathrm{MnO}$. From here, the further reduction goes through the liquid phase down to the final composition of about 45-52 wt pet $\mathrm{MnO}$, which means that the Comilog slag reaches liquidus composition close to $1748 \mathrm{~K}\left(1475{ }^{\circ} \mathrm{C}\right)$. A similar mechanism is also seen for the reduction of the primary Assmang slag. At temperatures from $1686 \mathrm{~K}$ to $1778 \mathrm{~K}\left(1413{ }^{\circ} \mathrm{C}\right.$ to $\left.1505{ }^{\circ} \mathrm{C}\right)$, the reduction of the primary slag from Assmang ore will take place from about 74 wt pet $\mathrm{MnO}$ in the presence of two stable phases, manganosite + liquid slag down to the liquidus composition of about 34 wt pet $\mathrm{MnO}$. Further reduction continues through the liquid phase down to the final composition of about $22-17$ wt pet $\mathrm{MnO}$ at $1778 \mathrm{~K}\left(1505^{\circ} \mathrm{C}\right)$. As such, the slag from Assmang ore will not reach a completely liquid zone at temperatures $<1778 \mathrm{~K}\left(1505^{\circ} \mathrm{C}\right)$ during the reduction in the presence of two stable phases, manganosite + liquid. The relatively small difference between the $\mathrm{MnO}$ content at liquidus and the content in the final slag inside the coke bed is an indication that much of the reduction occurs on top of the coke bed and the $\mathrm{MnO}$ content in the final slag is close to the liquidus composition. Typical slag 
Table III. Calculated Liquid Slag Composition Based on Measured Area Fraction by ImageJ ${ }^{\circledR}$ and EPMA Phase Analysis for Comilog Slags

\begin{tabular}{|c|c|c|c|c|c|c|c|}
\hline Slag Sample & & CM-1 & CM-2 & CM-3 & CM-4 & CM-5 & CM-6 \\
\hline Temperature (K) & & 1490 & 1550 & 1683 & 1748 & $>1683$ & $>1748$ \\
\hline \multirow[t]{3}{*}{ Pct Area Fraction } & monoxide & 64.6 & 66.7 & 62.7 & 15.8 & & \\
\hline & tephroite & 25.5 & 25.7 & 21.9 & 59.1 & 41.5 & 66.1 \\
\hline & galaxite & 9.90 & 7.64 & 15.4 & 25.1 & 58.5 & 33.9 \\
\hline Total MnO (Wt Pct) & & 86.8 & 86.1 & 85.0 & 62.9 & 45.5 & 52.1 \\
\hline \multirow[t]{9}{*}{ Liquid Composition } & $\mathrm{MnO}$ & 62.1 & 62.7 & 58.3 & 62.9 & 45.5 & 52.1 \\
\hline & $\mathrm{FeO}$ & 0.36 & 1.96 & 0.15 & 0.14 & 0.18 & 0.19 \\
\hline & $\mathrm{SiO}_{2}$ & 19.2 & 21.3 & 16.2 & 17.8 & 12.9 & 19.9 \\
\hline & $\mathrm{Al}_{2} \mathrm{O}_{3}$ & 16.9 & 13.8 & 25.2 & 14.9 & 39.1 & 21.2 \\
\hline & $\mathrm{CaO}$ & 0.16 & 0.17 & 0.27 & 0.21 & 0.39 & 1.86 \\
\hline & $\mathrm{MgO}$ & 0.70 & 0.24 & 0.89 & 0.49 & 0.91 & 1.29 \\
\hline & $\mathrm{BaO}$ & 0.02 & 0.05 & 0.05 & 0.05 & 0.65 & 0.24 \\
\hline & $\mathrm{TiO}_{2}$ & 0.19 & 0.21 & 0.25 & 0.45 & 0.39 & 0.19 \\
\hline & Total & 99.7 & 100.2 & 101.3 & 96.9 & 100 & 97.0 \\
\hline
\end{tabular}

Samples (CM-1)-(CM-4) were on top of the coke bed, and (CM-5)-(CM-6) are $5 \mathrm{~cm}$ into the coke bed.

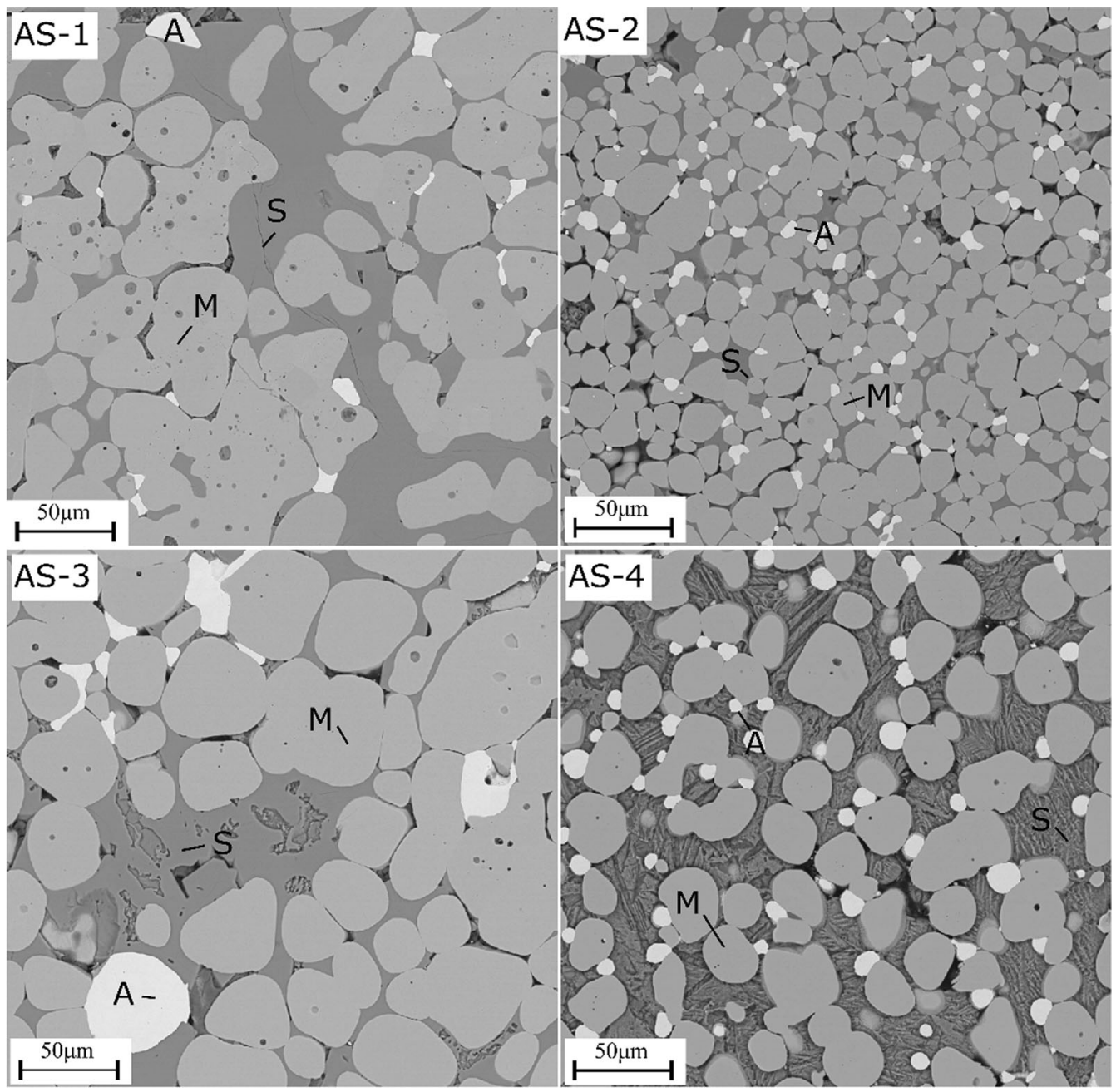

Fig. 5-BSE images of Assmang slag samples AS-1, AS-2, AS-3 and AS-4 collected from positions on top of the coke with temperatures $1493 \mathrm{~K}$ $\left(1220{ }^{\circ} \mathrm{C}\right), 1543 \mathrm{~K}\left(1270{ }^{\circ} \mathrm{C}\right), 1686 \mathrm{~K}\left(1413^{\circ} \mathrm{C}\right)$ and $1778 \mathrm{~K}\left(1505^{\circ} \mathrm{C}\right)$, respectively. $\mathrm{A}=$ alloy, $\mathrm{M}=$ monoxide, $\mathrm{S}=$ slag matrix. 
Table IV. Summary of the Average Compositions of the Phases Experimentally Observed From Assmang Slags (AS-1)-(AS-4) From the Top of the Coke Bed and Slag AS-5 $5 \mathrm{~cm}$ Below the Top of the Coke Bed

\begin{tabular}{|c|c|c|c|c|c|c|c|c|c|}
\hline \multirow[b]{2}{*}{ Identified Phase } & \multirow[b]{2}{*}{ Sample Name } & \multirow{2}{*}{$\begin{array}{c}\text { Temperature } \\
\mathrm{K}\left({ }^{\circ} \mathrm{C}^{\circ} \mathrm{C}\right)\end{array}$} & \multirow[b]{2}{*}{$\mathrm{MnO}$} & \multirow[b]{2}{*}{$\mathrm{SiO}_{2}$} & \multicolumn{2}{|c|}{ Wt Pct } & \multirow[b]{2}{*}{$\mathrm{CaO}$} & \multirow[b]{2}{*}{$\mathrm{FeO}$} & \multirow{2}{*}{ Total } \\
\hline & & & & & $\mathrm{Al}_{2} \mathrm{O}_{3}$ & $\mathrm{MgO}$ & & & \\
\hline \multirow{4}{*}{ Monoxide } & AS-1 & $1493(1220)$ & 89.4 & 0.16 & 0.04 & 0.44 & 0.72 & 7.29 & 98.05 \\
\hline & AS-2 & $1543(1270)$ & 84.5 & 0.12 & 0.06 & 0.55 & 1.52 & 10.2 & 96.95 \\
\hline & AS-3 & $1686(1413)$ & 86.1 & 0.05 & 0.10 & 0.50 & 1.40 & 4.40 & 92.55 \\
\hline & AS-4 & $1778(1505)$ & 83.1 & 0.4 & 0.20 & 2.73 & 3.06 & 8.09 & 97.58 \\
\hline \multirow[t]{4}{*}{ Slag Matrix } & AS-1 & $1493(1220)$ & 35.2 & 28.5 & 0.06 & 0.63 & 29.0 & 1.35 & 94.74 \\
\hline & AS-2 & $1543(1270)$ & 31.9 & 29.5 & 0.02 & 0.30 & 33.0 & 1.47 & 96.19 \\
\hline & AS-3 & $1686(1413)$ & 33.9 & 30.1 & 0.11 & 0.46 & 29.6 & 0.90 & 95.07 \\
\hline & AS-4 & $1778(1505)$ & 22.1 & 34.4 & 0.26 & 9.63 & 34.1 & 0.09 & 100.6 \\
\hline Light Gray (LG) & AS-5 & $>1778(1505)$ & 25.1 & 24.8 & 20.7 & 4.84 & 25.5 & 0.06 & 101.0 \\
\hline Dark Gray (DG) & AS-5 & $>1778(1505)$ & 15.1 & 29.8 & 7.41 & 7.80 & 37.7 & 0.03 & 97.84 \\
\hline
\end{tabular}
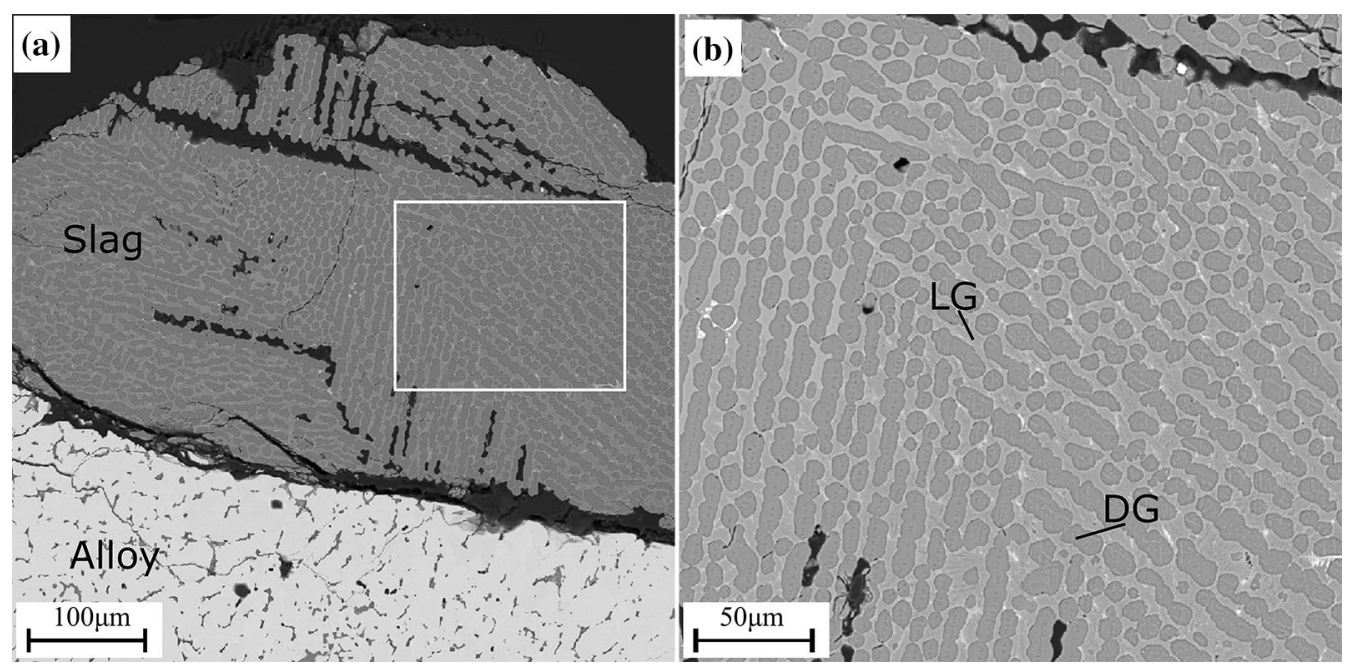

Fig. 6-BSE images of Assmang slag AS-5 (a) collected from positions $5 \mathrm{~cm}$ below the top of the coke bed with reference coke bed temperature at $1778 \mathrm{~K}\left(1505^{\circ} \mathrm{C}\right)$, and the area inside of the white rectangular line is higher magnification $(b) . \mathrm{A}=$ alloy, LG $=$ light gray phase, DG $=$ dark gray slag matrix.

Table V. Calculated Liquid Slag Composition Based on Measured Area Fraction by ImageJ ${ }^{\circledR}$ and EPMA Phase Analysis of Assmang Slags

\begin{tabular}{|c|c|c|c|c|c|c|}
\hline Slag sample & & AS-1 & AS-2 & AS-3 & AS-4 & AS-5 \\
\hline Temperature (K) & & 1493 & 1543 & 1686 & 1778 & 1778 \\
\hline \multirow[t]{2}{*}{ pct Area Fraction } & monoxide/LG & 63.6 & 71.0 & 82.7 & 50.7 & 19.3 \\
\hline & slag matrix & 36.4 & 29.0 & 17.3 & 49.3 & 80.7 \\
\hline Total MnO (wt pct) & & 69.7 & 69.3 & 74.6 & 49.4 & 17.1 \\
\hline \multirow[t]{9}{*}{ Liquid composition } & $\mathrm{MnO}$ & 35.2 & 31.9 & 33.5 & 22.1 & 17.1 \\
\hline & $\mathrm{FeO}$ & 1.35 & 1.47 & 0.90 & 0.89 & 0.03 \\
\hline & $\mathrm{SiO}_{2}$ & 28.5 & 29.5 & 32.6 & 34.4 & 28.8 \\
\hline & $\mathrm{Al}_{2} \mathrm{O}_{3}$ & 0.06 & 0.02 & 0.01 & 0.26 & 9.98 \\
\hline & $\mathrm{CaO}$ & 29.0 & 33.0 & 30.6 & 34.1 & 35.3 \\
\hline & $\mathrm{MgO}$ & 0.63 & 0.30 & 0.18 & 9.63 & 7.21 \\
\hline & $\mathrm{BaO}$ & 0.04 & 0.19 & 0.08 & 0.05 & 0.57 \\
\hline & $\mathrm{TiO}_{2}$ & 0.01 & 0.01 & 0.01 & 0.06 & 0.13 \\
\hline & total & 94.8 & 96.4 & 97.9 & 101.5 & 99.1 \\
\hline
\end{tabular}

Slags (AS-1)-(AS-4) were on top of the coke Bed and AS-5 is $5 \mathrm{~cm}$ into the coke bed. 


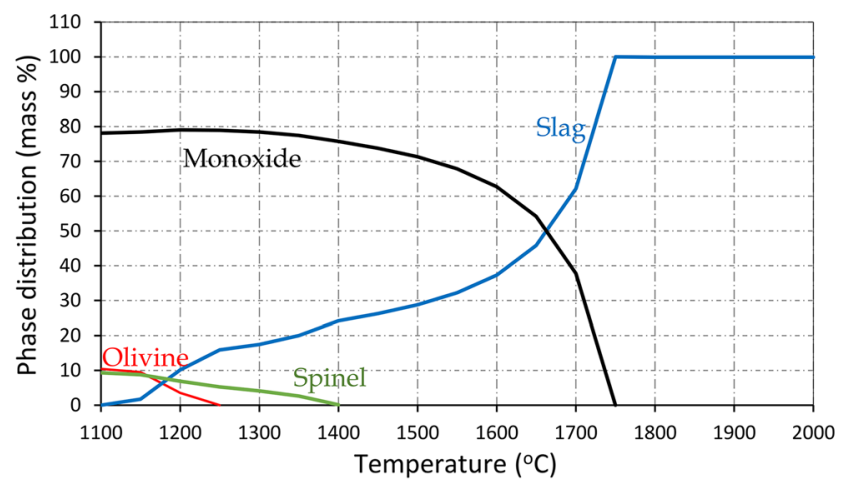

(a)

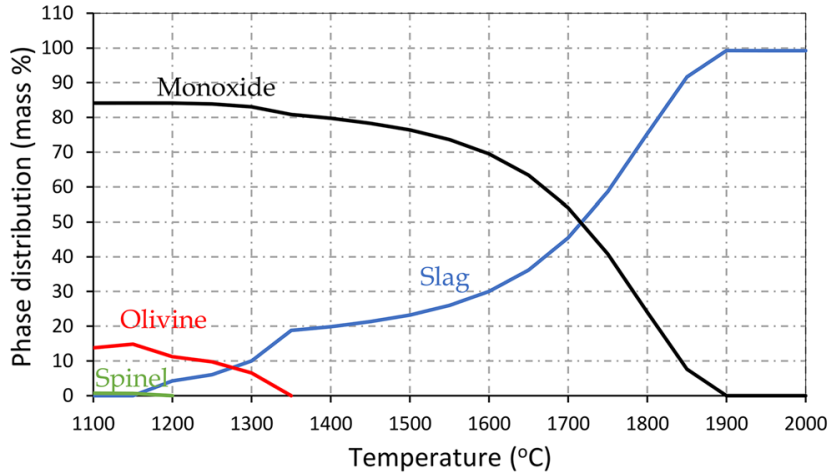

(c)

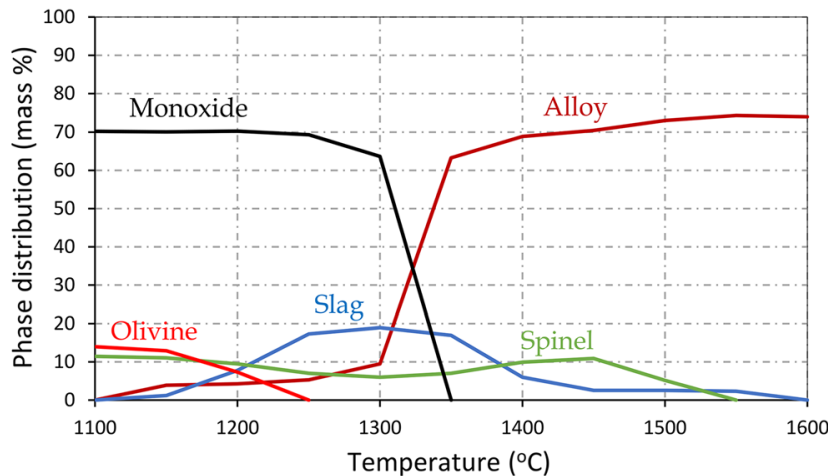

(b)

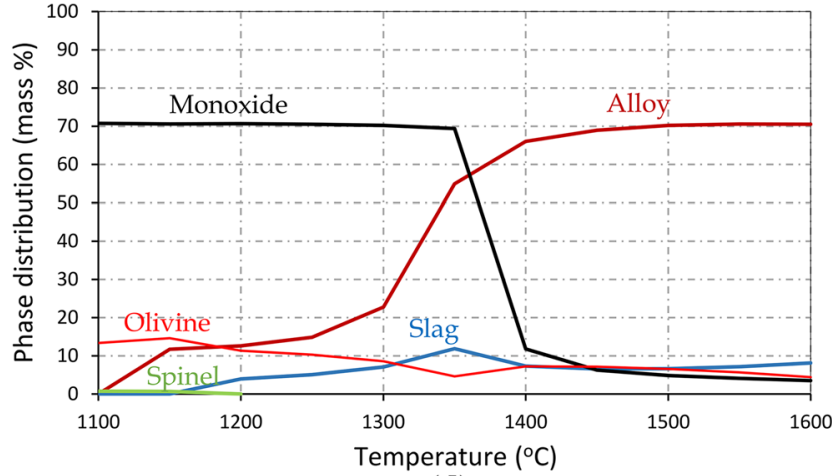

(d)

Fig. 7-Equilibrium phase distribution with increasing temperature that shows: $(a)$ phases in primary Comilog slag, $(b)$ phases when Comilog is in equilibrium with solid carbon, $(c)$ phases in primary Assmang slag, $(d)$ phases when Assmang is in equilibrium with solid carbon.

tapping temperatures from industrial SAF have been reported at $1723 \mathrm{~K}$ to $1773 \mathrm{~K}\left(1450{ }^{\circ} \mathrm{C}\right.$ to $\left.1500{ }^{\circ} \mathrm{C}\right) .{ }^{[1]}$ FactSage-based calculation of the content of $\mathrm{MnO}$ in the liquidus composition at $1773 \mathrm{~K}\left(1500{ }^{\circ} \mathrm{C}\right)$ for the reduced Comilog ore was 39.7 wt pet and 14.4 wt pet for Assmang, which is in close agreement with industrial data. ${ }^{[1]}$

The liquidus compositions are highly dependent on the oxides of the original ores and the basicity of the slag. As shown in Figure 8, a basic Assmang ore will have a lower $\mathrm{MnO}$ content in the liquid slag phase compared to an acidic Comilog ore, which is consistent with previous findings. ${ }^{[1,25]}$ A liquid slag phase on top of the coke bed, which coexists with the solid monoxide, has been observed to have a higher $\mathrm{MnO}$ content than calculated equilibrium values for both Comilog and Assmang slags. This shows that the experimental system was not at equilibrium. Some inconsistencies are observed, which are attributed to the heterogeneity of manganese ores. It is important to note that FactSage equilibrium calculation results cannot account for the heterogeneity of the ores. The $\mathrm{MnO}$ content in the liquid slag phase for slags inside the coke bed is slightly lower than slags on top of the coke bed, which shows that much of the reduction occurs on top of the coke bed.

The equilibrium composition of the alloy phase formed during carbothermic reduction of Comilog and Assmang slags presented in Table VII is highly dependent on temperature. The alloy phase is mainly Fe at the start of the reduction and becomes enriched in manganese with increase in temperature and further reduction of dissolved $\mathrm{MnO}$. In addition to temperature, metallization has been shown to vary considerably as size of alloy droplets, with the $\mathrm{Mn} / \mathrm{Fe}$ ratios increasing with increase in alloy particle size. It begins with metallic iron nucleation adjacent to the solid monoxide spheres within the liquid slag as shown in Figures 3 and 5. The observed $\mathrm{Mn} / \mathrm{Fe}$ ratios for the Comilog were approximately $0.04,0.96$ and 12.1 for the metal prills $(<10 \mu \mathrm{m})$, beads $(10$ to $100 \mu \mathrm{m})$ and bulk phase $(>100 \mu \mathrm{m})$, respectively. Whereas for Assmang, the $\mathrm{Mn} / \mathrm{Fe}$ ratios were approximately $0.04,3.75$ and 11.14 for the metal prills $(<10 \mu \mathrm{m})$, beads $(10$ to $100 \mu \mathrm{m})$ and bulk phase $(>$ $100 \mu \mathrm{m})$, respectively. In contrast to Assmang (Figure 5), the metal prills in Comilog (Figure 3) are notably less mainly because Comilog contains less Fe compared to Assmang as presented in Table I.

\section{Reduction Mechanism}

To elucidate the reduction mechanism based on the above discussions on monoxide phase development and its dissolution as well as slag reduction path, a simplified illustration of the slag-coke bed system shown in Figure 9 is considered. The presented schematic is stepwise for clarity even though the process is continuous. 
Table VI. Calculated Equilibrium Composition (Wt Pct) of Liquid Slag Phase for Comilog and Assmang Reduction (FactSage 7.3)

\begin{tabular}{|c|c|c|c|c|c|c|c|}
\hline Ore & Temperature, $\mathrm{K}\left({ }^{\circ} \mathrm{C}\right)$ & $\mathrm{MnO}$ & $\mathrm{FeO}$ & $\mathrm{SiO}_{2}$ & $\mathrm{Al}_{2} \mathrm{O}_{3}$ & $\mathrm{CaO}$ & $\mathrm{MgO}$ \\
\hline \multirow[t]{6}{*}{ Comilog } & \multicolumn{7}{|c|}{ (initial slag formation at $1150^{\circ} \mathrm{C}$ ) } \\
\hline & $1473(1200)$ & 55.4 & 0.09 & 26.2 & 12.9 & 5.4 & 0.1 \\
\hline & $1573(1300)$ & 59.3 & 0.05 & 22.1 & 15.8 & 2.6 & 0.1 \\
\hline & $1673(1400)$ & 52.0 & 0.03 & 22.6 & 22.3 & 2.7 & 0.4 \\
\hline & $1773(1500)$ & 39.7 & 0.03 & 23.8 & 33.2 & 2.8 & 0.5 \\
\hline & $1873(1600)$ & 26.1 & 0.02 & 22.4 & 45.2 & 5.3 & 1.0 \\
\hline \multirow[t]{6}{*}{ Assmang } & \multicolumn{7}{|c|}{ (initial slag formation at $1200{ }^{\circ} \mathrm{C}$ ) } \\
\hline & $1473(1200)$ & 36.9 & 0.05 & 28.8 & 11.1 & 18.7 & 4.5 \\
\hline & $1573(1300)$ & 43.4 & 0.04 & 29.5 & 6.3 & 14.2 & 6.6 \\
\hline & $1673(1400)$ & 30.9 & 0.02 & 31.2 & 6.8 & 16.3 & 14.8 \\
\hline & $1773(1500)$ & 14.4 & 0.01 & 35.3 & 7.5 & 18.8 & 23.9 \\
\hline & $1873(1600)$ & 7.0 & $<0.01$ & 38.2 & 6.1 & 16.4 & 32.7 \\
\hline
\end{tabular}

Table VII. Calculated Equilibrium Composition (Wt Pct) of the Liquid Alloy for the Reduction of Comilog and Assmang Slags (FactSage 7.3)

\begin{tabular}{|c|c|c|c|c|c|c|}
\hline Ore & Temperature, $\mathrm{K}\left({ }^{\circ} \mathrm{C}\right)$ & $\mathrm{Mn}$ & $\mathrm{Fe}$ & $\mathrm{Si}$ & $\mathrm{C}$ & $\mathrm{Mn} / \mathrm{Fe}$ \\
\hline \multirow[t]{6}{*}{ Comilog } & $1373(1100)$ & 2.1 & 93.6 & - & 4.3 & 0.02 \\
\hline & $1473(1200)$ & 11.7 & 83.5 & $<0.01$ & 4.8 & 0.14 \\
\hline & $1573(1300)$ & 55.4 & 38.3 & $<0.01$ & 6.3 & 1.45 \\
\hline & $1673(1400)$ & 86.0 & 5.3 & 1.8 & 6.8 & 16.2 \\
\hline & $1773(1500)$ & 85.5 & 5.0 & 2.7 & 6.8 & 17.1 \\
\hline & $1873(1600)$ & 85.2 & 4.9 & 2.7 & 7.1 & 17.4 \\
\hline \multirow[t]{6}{*}{ Assmang } & $1373(1100)$ & 1.8 & 93.9 & - & 4.3 & 0.02 \\
\hline & $1473(1200)$ & 10.2 & 85.1 & $<0.01$ & 4.8 & 0.12 \\
\hline & $1573(1300)$ & 46.5 & 47.4 & 0.02 & 6.0 & 0.98 \\
\hline & $1673(1400)$ & 76.2 & 16.4 & 0.5 & 7.0 & 4.64 \\
\hline & $1773(1500)$ & 75.6 & 15.4 & 2.3 & 7.0 & 4.91 \\
\hline & $1873(1600)$ & 75.0 & 15.3 & 2.8 & 6.8 & 4.90 \\
\hline
\end{tabular}

Table VIII. Composition (wt pet) of the Monoxide Phase During Carbothermic Reduction of Comilog and Assmang (FactSage 7.3)

\begin{tabular}{|c|c|c|c|c|c|c|c|c|c|c|}
\hline \multirow{2}{*}{$\begin{array}{l}\text { Temperature } \\
\mathrm{K}\left({ }^{\circ} \mathrm{C}\right)\end{array}$} & \multicolumn{5}{|c|}{ Comilog Monoxide Phase } & \multicolumn{5}{|c|}{ Assmang Monoxide Phase } \\
\hline & $\mathrm{MnO}$ & $\mathrm{Al}_{2} \mathrm{O}_{3}$ & $\mathrm{MgO}$ & $\mathrm{CaO}$ & $\mathrm{FeO}$ & $\mathrm{MnO}$ & $\mathrm{MgO}$ & $\mathrm{CaO}$ & $\mathrm{FeO}$ & $\mathrm{Al}_{2} \mathrm{O}_{3}$ \\
\hline $1373(1100)$ & 98.7 & 0.8 & 0.06 & 0.08 & 0.3 & 90.5 & 8.9 & 0.2 & 0.4 & 0.04 \\
\hline $1473(1200)$ & 98.8 & 1.0 & 0.07 & 0.03 & 0.1 & 90.1 & 9.4 & 0.2 & 0.2 & 0.08 \\
\hline $1573(1300)$ & 98.6 & 1.2 & 0.10 & 0.02 & 0.03 & 89.9 & 9.7 & 0.2 & 0.07 & 0.06 \\
\hline $1673(1400)$ & \multirow{3}{*}{\multicolumn{5}{|c|}{ monoxide completely dissolved in liquid slag }} & 55.0 & 44.9 & 0.1 & 0.05 & 0.04 \\
\hline $1773(1500)$ & & & & & & 15.1 & 84.8 & 0.02 & 0.03 & 0.03 \\
\hline $1873(1600)$ & & & & & & 5.5 & 94.4 & 0.01 & 0.02 & 0.02 \\
\hline
\end{tabular}

The reaction system involves five phases, namely, liquid slag with solid $\mathrm{MnO}$, metal, carbon and gas, as illustrated in Figure 9. The initial slag formed is mainly liquid + solid monoxide phase. The initial alloy forms Fe prills mainly located in areas outside and adjacent to the solid monoxide phase. As evidenced in micrographs in Figures 3 and 5, this indicates that Fe is formed in the prereduction zone prior to slag reduction in the coke bed. The alloy droplets increase in size as well as wt pct $\mathrm{Mn}$ and wt pet $\mathrm{C}$. This is due to an increased proximity to reductant carbon, where it is reasonable to consider $\mathrm{MnO}$ reduction to be highly significant at the slag/coke interface. At equilibrium, the activity of $\mathrm{MnO}$ is equal in the solid monoxide phase and liquid phase. Therefore, the activity of $\mathrm{MnO}$ remains high in the presence of solid monoxide. On the other hand, metallic iron lowers the $\mathrm{Mn}$ activity in the reaction system to increase reduction of $\mathrm{MnO}$ at the slag/coke interface and the $\mathrm{Mn}$ is added to the iron metal prills, thus increasing the wt pet Mn. The presence of solid monoxide phase will make the slag 
highly viscous. However, reduction will occur on top of the coke bed with an increased dissolution of monoxide in slag rendering the slag fluid enough to trickle down the coke bed. Little reduction will occur inside the coke bed area due to the lower $\mathrm{MnO}$ activity which emanates from complete dissolution of solid monoxide phase. As such, the slag will be tapped at a composition close to the liquidus composition as shown in Figure 8.

\section{CONCLUSIONS}

The reduction and slag dissolution behavior of Comilog and Assmang ores was studied experimentally in a setup that simulates the industrial SAF. The results were discussed based on thermodynamic calculations where FactSage 7.3 thermochemical software was used

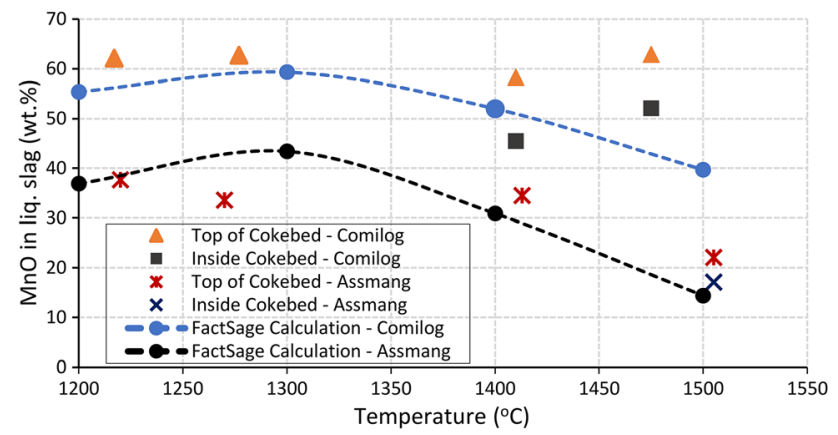

Fig. 8-Calculated equilibrium content of $\mathrm{MnO}$ vs temperature for the liquid phase. Experimental $\mathrm{MnO}$ content $v$ s temperature in the liquid phase relative to their position within the coke bed zone is also shown. to calculate phase development and compositional changes during the formation and reduction of slag. The main conclusions can be summarized as follows:

1. The solid monoxide phase in Comilog has been found to be $>99 \mathrm{wt}$ pet $\mathrm{MnO}$. In contrast to Comilog, the monoxide solution phase in Assmang has significantly high $\mathrm{FeO}$ content and forms a ( $\mathrm{Mn}, \mathrm{Mg}, \mathrm{Fe}) \mathrm{O}$ solid solution, which becomes more enriched in $\mathrm{MgO}$ with increases in temperature and reduction extent. Due to lower concentration of $\mathrm{CO}$ gas for prereduction in this experimental setup, iron oxides are reduced to $\mathrm{FeO}$ instead of $\mathrm{Fe}$ and subsequently $\mathrm{FeO}$ is stabilized in the monoxide solid solution.

2. Comilog forms an initial liquid slag phase at $1423 \mathrm{~K}$ $\left(1150{ }^{\circ} \mathrm{C}\right)$, which is lower compared to $1473 \mathrm{~K}(1200$ $\left.{ }^{\circ} \mathrm{C}\right)$ for Assmang. Furthermore, much of the reduction occurs on top of the coke bed until liquidus composition is reached. The $\mathrm{MnO}$ content of the liquid slag will then be close to the liquidus composition, and Assmang slag has a higher liquidus temperature compared to Comilog.

3. During carbothermic reduction of manganese ores, metallization begins with nucleation of metallic iron adjacent to the solid monoxide spheres and Assmang ore produces considerably more metal prills compared to Comilog mainly because of its relatively higher content of iron oxides.

4. Phase equilibria calculated using FactSage 7.3 thermochemical software are useful in highlighting the trends in the reduction of Comilog and Assmang slags. However, the equilibrium calculations cannot account for the heterogeneity of the ores observed from experiments and thus, there exists some minor inconsistencies.

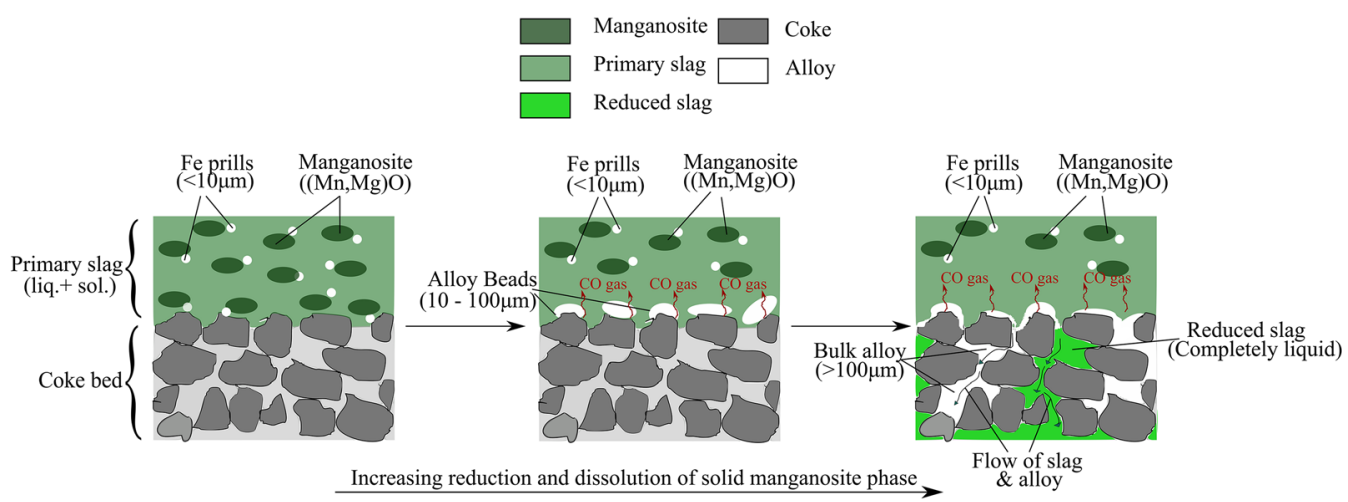

Fig. 9-Schematic illustration of the interactions in the slag-coke bed system. 


\section{ACKNOWLEDGMENTS}

This work is part of the PreMa project, which has received funding from the European Union's Horizon 2020 Research and Innovation Programme under Grant Agreement No. 820561 and industry partners Eramet, Ferrogroble, Transalloys, OFZ and Outotec. The authors greatly appreciate the EPMA analysis done by Morten Peder Raanes.

\section{CONFLICT OF INTEREST}

The authors declare that they have no conflict of interest.

\section{FUNDING}

Open access funding provided by NTNU Norwegian University of Science and Technology (incl St. Olavs Hospital - Trondheim University Hospital).

\section{OPEN ACCESS}

This article is licensed under a Creative Commons Attribution 4.0 International License, which permits use, sharing, adaptation, distribution and reproduction in any medium or format, as long as you give appropriate credit to the original author(s) and the source, provide a link to the Creative Commons licence, and indicate if changes were made. The images or other third party material in this article are included in the article's Creative Commons licence, unless indicated otherwise in a credit line to the material. If material is not included in the article's Creative Commons licence and your intended use is not permitted by statutory regulation or exceeds the permitted use, you will need to obtain permission directly from the copyright holder. To view a copy of this licence, visit http://creat ivecommons.org/licenses/by/4.0/.

\section{REFERENCES}

1. S.E. Olsen, M. Tangstad, and T. Lindstad: Production of Manganese Ferroalloys, Tapir Academic Press, Trondheim, 2007.

2. L.A. Corathers: Minerals Yearbook: Manganese, United States Geological Survey, 2008.

3. A. Ahmed, H. Haifa, M.K. El-Fawakhry, H. El-Faramawy, and M. Eissa: J. Iron Steel Res. Int., 2014, vol. 21, pp. 666-72.

4. I.S. Çardakli, N. SevInç, and T. Öztürk: Turkish J. Eng. Environ. Sci., 2011, vol. 35, pp. 31-8.
5. M. Tangstad, E. Ringdalen, E. Manilla, and D. Davila: JOM., 2017, vol. 69, pp. 358-64.

6. M. Eissa, S. Ghali, A. Ahmed, and H. El-Faramawy: Ironmak. Steelmak., 2012, vol. 39, pp. 419-30.

7. J. Kunze and R. Degel: 10th Int. Ferroalloys Congr., 2004, pp. $444-54$.

8. J.D. Steenkamp and J. Basson: J. South. African Inst. Min. Metall., 2013, vol. 113, pp. 667-76.

9. B. Sorensen, S. Gaal, M. Tangstad, E. Ringdalen, R. Kononov, and O. Ostrovski: 12th Int. Ferroalloys Congr., 2010, pp. 439-48.

10. Y.E. Lee and L. Kolbeinsen: Metall. Mater. Trans. B, 2021, pp. $1-5$.

11. J. Safarian, L. Kolbeinsen, M. Tangstad, and G. Tranell: Metall. Mater. Trans. B., 2009, vol. 40B, pp. 929-39.

12. M.A. Reuter and J.S.J. Van Deventer: Thermochim. Acta, 1988, pp. $99-106$.

13. O.I. Ostrovski and T.J.M. Webb: ISIJ Int., 1995, vol. 35, pp. 1331-39.

14. M. Kumar, S. Ranganathan, and S.N. Sinha: 11th Int. Ferroalloys Congr., 2007, pp. 241-46.

15. R.S. Braga, C. Takano, and M.B. Mourão: Ironmak. Steelmak., 2007, vol. 34, pp. 279-84.

16. A. Roine: in HSC Chemistry Software, v 10.0.4.3, Metso Outotec, Pori, 2021

17. S. Gaal, E. Ringdalen, D. Vaganov, and M. Tangstad: 8th Int. Conf. Molten Slags, Fluxes Salts, 2009, pp. 101-09.

18. E. Ringdalen, M. Tangstad, and T. Brynjulfsen: 14th Int. Ferroalloys Congr., 2015, pp. 436-45.

19. T. Brynjulfsen and M. Tangstad: 13th Int. Ferroalloys Congr., 2013, pp. 137-47.

20. S. Gaal, D. Lou, S. Wasbø, B. Ravary, and M. Tangstad: 11th Int. Ferroalloys Congr., 2007, pp. 247-57.

21. J. Safarian, G. Tranell, L. Kolbeinsen, M. Tangstad, S. Gaal, and J. Kaczorowski: Metall. Mater. Trans. B., 2008, vol. 39B, pp. $702-12$.

22. T. Coetsee: Minerals., 2021, vol. 11, pp. 1-15.

23. T. Coetsee: SSRN Electron. J., 2021, vol. 1, pp. 27-29.

24. L. Holappa and Y. Xiao: J. South African Inst. Min. Metall., 2004, vol. 104, pp. 429-37.

25. X. Li, K. Tang, and M. Tangstad: Minerals., 2020, vol. 10, pp. $1-16$.

26. M. Tangstad and S.E. Olsen: 5th Int. Conf. Molten Slags, Fluxes Salts 97, 1997, pp. 549-55.

27. T. Coetsee, J. Zietsman, and C. Pistorius: Miner. Process. Extr. Metall., 2014, vol. 123, pp. 141-47.

28. M. Tangstad: Ph.D. Thesis, The Norwegian Institute of Technology, Trondheim, Norway, 1996.

29. M.J. Peterson, J.R. Manuel, and S. Hapugoda: Appl. Earth Sci. Trans. Inst. Min. Metall., 2020, vol. 0, pp. 1-21.

30. C.W. Bale, E. Bélisle, P. Chartrand, S.A. Decterov, G. Eriksson, A.E. Gheribi, K. Hack, I.H. Jung, Y.B. Kang, J. Melançon, A.D. Pelton, S. Petersen, C. Robelin, J. Sangster, P. Spencer, and M.A. Van Ende: Calphad Comput. Coupling Phase Diagrams Thermochem., 2016, vol. 55, pp. 1-19.

31. M. Allibert, H. Gaye, J. Geiseler, D. Janke, B.J. Keene, D. Kirner, M. Kowalski, J. Lehmann, K.C. Mills, D. Neuschütz, R. Parra, C. Saint-Jours, P.J. Spencer, M. Susa, M. Tmar, E. Woermann: in Slag Atlas, $2^{\text {nd }}$ ed., Verein Deutscher Eisenhüttenleute, ed., Verlag Stahleisen GmbH, Düsseldorf, 1995, p. 166.

Publisher's Note Springer Nature remains neutral with regard to jurisdictional claims in published maps and institutional affiliations. 